\title{
Spillover Effects from the ECB's Unconventional Monetary Policies: The Case of Denmark, Norway and Sweden
}

\author{
By Arthur Korus*
}

\begin{abstract}
Using event-study techniques we investigate the impact of ECB's announcements of nonstandard policy measures on a broad range of financial assets from Denmark, Norway and Sweden. We find evidence that unconventional monetary policy announcements by the ECB resulted in pronounced spillovers to Denmark, Norway and Sweden. In particular, our results suggest that medium- and long-term government bond yields, corporate bond yields and CDS spreads were affected by ECB's announcements of non-standard policy measures. Our empirical results indicate that the portfolio rebalancing channel played an important role in the transmission of ECB's non-standard policy measures on mediumand long-term government bonds and corporate bond yields. However, it also seems that declining government bond yields transmitted to decreasing corporate bond yields. Moreover, our results suggest that benchmark stock market indices and exchange rates vis-à-vis the euro were mainly unaffected by ECB's announcements of unconventional monetary policies. Furthermore, we find pronounced spillover effects from Forward Guidance statements, Securities Markets Programme announcements, and Corporate Sector Purchase Programme announcements on financial assets from Denmark, Norway and Sweden. Though, our results highly depend on the monetary policy surprise measure used in our regressions and the degree of policy anticipation.
\end{abstract}

Keywords: ECB, Event-Study, Monetary Policy Spillovers, Nordic countries

\section{Introduction}

In recent years the European Central Bank (ECB) has announced and implemented unconventional monetary policies (UMPs) in response to both the financial crisis and the euro area sovereign debt crisis. The ECB has announced and adopted a broad range of non-standard monetary policy measures, including the purchase of euro area government bonds and corporate bonds. Moreover, the ECB has implemented a series of key policy rate changes. Due to these changes, key policy rates have even reached negative territory. Empirical evidence suggests that the ECB's unconventional monetary policies, adopted since 2008, have influenced macroeconomic variables and financial assets in euro area countries (Abbassi and Linzert 2012, Peersman 2012, Ghysels et al. 2013, Andrade et al. 2016, Gambetti and Musso 2017). Moreover, several studies document spillover effects of euro area non-standard monetary policy measures on advanced economies and emerging markets (Fratzscher et al. 2014, Falagiarda et al. 2015, Georgiadis and Gräb 2015, Potjagailo 2016). This strand of literature shows that

*Research Assistant, Chair for Macroeconomic Theory and Policy, Schumpeter School of Business and Economics, University of Wuppertal, Germany. 
the ECB's unconventional monetary policies have had price effects and output effects on non-euro area countries. However, evidence regarding the spillover effects resulting from the ECB's unconventional monetary policies to small advanced open economies outside the euro area remains scarce (Bernhard and Ebner 2016, Bluwstein and Canova 2016). To fill this gap, we empirically investigate the impact of the ECB's announcements of non-standard policy measures on a broad range of financial assets from Denmark, Norway and Sweden.

In general, Denmark, Norway and Sweden are small, advanced and highly open economies for which the euro area countries are important trading partners and providers of capital. Moreover, these countries share a common model, namely the Nordic model (IMF 2013b). The Nordic model is marked by growthenhancing trade, financial openness, stable public finances, cooperative labour markets and an equitable income distribution. The Nordic model resulted in macroeconomic stability and a history of fiscal prudence in Denmark, Norway and Sweden. These features established the aforementioned countries as safe havens in the eyes of financial markets during the financial and the euro area sovereign debt crises. Moreover, the banking sector is relative large and highly-concentrated in the Nordic countries. However, important differences between the three countries exist (IMF 2013b). For instance, Norway and Sweden follow inflation targeting with freely floating exchange rates. Whereas Denmark follows a fixed-exchange rate policy vis-à-vis the euro area and participates in the European Exchange Rate Mechanism, ERM2. Thus, the common approach on the one hand and differences between our selected countries on the other hand makes it interesting to study the effects of the ECB's unconventional monetary policies on financial variables from Denmark, Norway and Sweden.

We find evidence that UMP announcements by the ECB resulted in pronounced spillovers to Denmark, Norway and Sweden. In particular, our results suggest that medium- and long-term government bond yields, corporate bond yields and Credit Default Swaps (CDS) spreads were affected by the ECB's announcements of non-standard policy measures. Although our estimation strategy does not allow to identify the underlying transmission channels, through which the ECB's UMP measures may affect financial assets from our countries of interest, our results do indicate that the portfolio rebalancing channel played an important role in the transmission of the ECB's non-standard policy measures on mediumand long-term government bonds and corporate bond yields. However, it also seems that declining government bond yields transmitted to decreasing corporate bond yields. Moreover, our results suggest that benchmark stock market indices and exchange rates vis-à-vis the euro were largely unaffected by the ECB's announcements of unconventional monetary policies.

Furthermore, we find pronounced spillover effects from Forward Guidance (FWG) statements, Securities Markets Programme (SMP) announcements and Corporate Sector Purchase Programme (CSPP) announcements on financial assets from Denmark, Norway and Sweden. While spillover effects from the Outright Monetary Transactions (OMT) and Public Sector Purchase Programme (PSPP) announcements on financial variables from our countries of interest were limited. Our results suggest that SMP operated perhaps via the portfolio rebalancing 
channel, the confidence and the exchange rate channel. The OMT mainly operated via the confidence channel. Furthermore, we argue that FWG statements spilled over to all countries mainly via the signalling channel. Regarding PSPP announcements, we argue that PSPP mainly operated via the portfolio rebalancing channel. Whereas our results indicate that CSPP announcements possibly spilled over via both the confidence and exchange rate channel.

The remainder of the paper is organized as follows. First, we take a brief look at the literature on monetary spillovers. Section 3 gives an overview of the unconventional monetary policies adopted by the ECB since 2008. In Section 4 we discuss several transmission channels through which unconventional monetary policy in advanced economies spills over internationally. In Section 5 we formulate specific expectations regarding the impact of the ECB's unconventional monetary policies on financial assets from Denmark, Norway and Sweden. Section 6 presents our empirical methodology and estimation results, while Section 7 concludes.

\section{Literature Review}

So far, many studies have focused on the impact of unconventional monetary policy measures on domestic variables (see Angelini et al. 2011, Gagnon et al. 2011, Krishnamurthy and Vissing-Jorgensen 2011, Abbassi and Linzert 2012, Baumeister and Benati 2013, Krishnamurthy et al. 2014, Andrade et al. 2016). For the euro area, the literature suggests that the ECB's unconventional monetary policies positively affected regional output (Lewis and Roth 2015). However, it seems that conventional monetary policy measures had a stronger influence on regional output than non-standard monetary policy measures (Peersman 2012). Moreover, Lewis and Roth (2015) show that the ECB's non-standard policy measures only slightly influenced inflation in the euro area. Moreover, the ECB's UMP measures led to declining market spreads (Abbassi and Linzert 2012) and a reduction in the term premia (Ghysels et al. 2013). Furthermore, there is evidence that the ECB's UMP measures reduced the yields of euro area long-term sovereign bonds (Ghysels et al. 2013, Andrade et al. 2016). Andrade et al. (2016) also show that the ECB's non-standard policy measures led to increasing share prices of banks holding a high share of government bonds in their portfolio.

In recent years, the analysis of spillover effects of such policies has received more attention. Many studies focus on the analysis of spillover effects of the Federal Reserve's (FED) non-standard monetary policies on advanced and emerging economies. Empirical evidence shows that the FED's UMP measures led to a depreciation of the US dollar, lower global short-term interest rates, falling global long-term government bond yields and declining corporate bond yields (Chen et al. 2012, Glick and Leduc 2012, Diez and Presno 2014, Fratzscher et al. 2013, IMF 2013a, Berge and Cao 2014, Glick and Leduc 2015, Neely 2015). Moreover, this literature shows that the effects of the FED's non-standard policy measures on global equity prices and capital flows were more ambiguous. 
Chen et al. (2012) analyse the international spillover effects of unconventional policy actions taken by central banks with a focus on the US asset purchase program. They find that the US asset purchase programs increased asset prices globally. The IMF (2013a) finds that early FED's announcements of UMP measures had stronger effects on global asset prices than later announcements. Fratzscher et al. (2013) elaborate on the international spillover effects of US quantitative easing (QE). They show that the FED's QE policies influenced portfolio flows and asset prices both in the US and globally. Moreover, they conclude that QE 1 led to a substantial rebalancing in global portfolios whereby investors turned to US markets. Hence, QE 1 led to an appreciation of the US dollar, lower US bond yields and higher equity prices on the US stock markets. In contrast to QE 1, QE 2 led to portfolio rebalancing in the opposite direction. Fratzscher et al. (2013) also show that the spillover effects of FED operations, such as government bond purchases, were larger than the effects of the FED's announcements of UMP measures. Furthermore, their findings suggest that a fixed exchange rate regime did not insulate from the FED's non-standard monetary policies.

While a large number of studies which elaborate on the impact of FED's nonstandard policy measures on economic and financial variables in other countries exist, only a few studies focus on spillovers from the ECB's unconventional monetary policies to non-euro area countries. Fratzscher et al. (2014) and Georgiadis and Gräb (2015) investigate spillover effects from the ECB's nonstandard policy measures on global financial markets. Both studies find that ECB UMP measures boosted equity prices globally, caused the euro to depreciate vis-àvis advanced and emerging market economy currencies and hardly influenced global bond yields. Georgiadis and Gräb (2015) show that scope and size of spillover effects across economies depended on differences in economies' financial openness, the exchange rate regime, the degree of financial and trade integration with the euro area and a countries attractiveness for carry trades. Additionally, Fratzscher et al. (2014) report that ECB non-standard policy measures reduced risk aversion and lowered credit risk globally. Moreover, they conclude that the ECB's non-standard policy measures exerted limited international effects because ECB policies resulted in modest effects on international portfolio flows. Chen et al. (2012) argue that the international spillover effects of the FED's unconventional monetary policy measures were stronger than those of ECB policies.

Falagiarda et al. (2015) study the effects of the ECB's non-standard policy measures on financial variables from non-euro area EU countries in Central and Eastern Europe (CEE). Using an event-study analysis they find that ECB UMP measures spilled over to CEE countries. In particular, sovereign bond yields were affected by ECB announcements of UMP measures. They find no impact on exchange rates vis-à-vis the euro, equity prices and CDS spreads. Furthermore, their results suggest that spillovers from SMP announcements were the most pronounced. The spillover effects of both OMT and PSPP on financial assets from CEE countries was limited. Potjagailo (2016) elaborates on the spillover effects 
from euro area monetary policy shocks to thirteen EU countries outside the euro area and finds that these shocks decreased interest rates and reduced uncertainty.

So far, evidence regarding the spillover effects from non-standard monetary policies of the ECB on small, open advanced economies remains scarce (Bernhard and Ebner 2016, Bluwstein and Canova 2016). By using a Bayesian mixedfrequency structural vector autoregressive technique, Bluwstein and Canova (2016) document international spillovers but they find that there was considerable cross-country heterogeneity. They document that a flexible exchange rate will not insulate non-euro area countries from importing non-standard ECB policy measures. Bernhard and Ebner (2016) investigate cross-border spillover effects of unconventional monetary policies on Swiss asset prices. By using an event-study setting and the change in 10-year government bond futures as a proxy for market anticipation, they find that non-standard monetary policies conducted by the FED, the ECB, the BoE and the BoJ exerted spillover effects on Swiss asset prices whereby ECB announcements had the strongest impact on financial variables from Switzerland. Furthermore, they show evidence that the effects of foreign UMP surprises on Swiss asset prices were less pronounced after the introduction of the Swiss franc/euro exchange rate floor of 1.20 francs per euro.

We contribute to the existing literature by assessing the effects of the ECB's non-standard policy measure announcements on small, open advanced economies. Our paper focuses on the impact of ECB announcements of UMP measures on a broad set of financial variables from three Nordic countries, namely Denmark, Norway and Sweden. Moreover, to the best of our knowledge, we are the first to analyse the impact of the ECB's announcements of unconventional monetary policies on a broad range of financial assets from Denmark, Norway and Sweden.

\section{The ECB's Unconventional Monetary Policy Measures}

During the global financial crisis and sovereign debt crisis, the ECB decreased its key interest rates significantly. The main refinancing rate was set at zero and the deposit facility rate has even been negative for some time. At the same time, the ECB has used, besides conventional monetary policy tools, unconventional monetary policy tools. Early on in the financial crisis, the ECB adopted several non-standard monetary policy measures in order to rekindle the functioning of the interbank money market. In order to ensure a smooth functioning of the interbank money market, the ECB introduced an unlimited provision of liquidity through a fixed-rate full allotment tender procedure (FRTPFA). This policy tool allows banks to lend an unlimited amount of euros at the main refinancing rate, subject to appropriate collateral. This measure ensured that the high demand for liquidity could be satisfied. Further, the list of eligible collateral (COLL) was extended. The extension of the list of eligible collateral accepted in Eurosystem refinancing operations allowed banks to refinance a larger part of their balance sheet with the Eurosystem. The aforementioned unconventional monetary policy measures ensured that euro area banks, with access to the auctions of the $\mathrm{ECB}$, have received an almost unlimited refinancing. 
The ECB also introduced longer-term refinancing operations (LTRO) with maturities from three months up to three years. Thus, the ECB provided long-term liquidity to euro area banks. Objectives of the longer-term refinancing operations were to improve liquidity conditions to banks and to reduce tensions within the interbank money market. Furthermore, the ECB established foreign currency lines (FOR) with several central banks. The ECB temporarily provided liquidity in foreign currencies, at various maturities, and against euro-denominated collateral. For this, the ECB used currency arrangements, notably with the FED. Thereby it was possible to avoid a massive shortfall in the US dollar. Hence, the aim of this non-standard monetary policy measure was to improve banks foreign currency funding.

In May 2009, the ECB introduced the Enhanced Credit Support (ECS). The ECS included the fixed-rate full allotment, the expansion of the list of eligible collateral, longer-term liquidity provision, liquidity provision in foreign currency, and purchases of covered bonds. The aim of the Covered Bond Purchasing Programme (CBPP1) was to stabilize the covered bond market, which is a primary source of funding for banks in large parts of the euro area, and to eliminate banks refinancing problems. Within the first Covered Bond Purchasing Programme, the ECB purchased covered bonds in the amount of 60 billion euro. In November 2011, the Eurosystem launched a second Covered Bond Purchasing Programme (CBPP2). CBPP2 encompassed an aggregated volume of 40 billion euro. The program ended, as planned, in October 2012, when it reached a nominal value of 16.4 billion Euros. In October 2014, the third CBPP (CBPP3) was introduced with duration of two years. The objective of the third CBPP was to improve monetary transmission and to bring inflation rates closer to the inflation target of the ECB.

In May 2010, the Securities Market Programme (SMP) was announced by the ECB. SMP involved purchases of euro area government bonds on the secondary markets. Liquidity injected through the SMP was sterilized through specific operations. Objectives of the SMP were to address the malfunctioning of securities markets and to restore the monetary policy transmission mechanism. At the peak, the volume of sovereign bonds held by the ECB amounted to 210 billion. The ECB announced an Outright Monetary Transactions (OMT) program in August 2012. OMT included transactions in secondary sovereign bond markets with no quantitative limits conditional on certain domestic conditions. With the introduction of the OMT, the SMP program was terminated. The overall aim of OMT was to remove monetary and financial fragmentation of the euro area. So far, OMT has never been activated. Nevertheless, its announcement reassured financial markets and especially sovereign bond markets (Altavilla et al. 2014).

Furthermore, during the sovereign debt crisis the ECB changed its monetary policy communication strategy. Namely in July 2013, the ECB introduced forward guidance (FWG) as an additional non-standard monetary policy tool. Forward guidance corresponds to a commitment on future interest rate decisions, so as to influence not only short-term rates, but also long-term rates which are largely determined by expectations on future short-term rates (Chinn 2013). Hence, since July 2013 the ECB has been providing explicit statements on the future path of the ECB's policy interest rates conditional on the outlook for price stability. The aim 
of forward guidance is to clarify the Governing Council's assessment of the inflation outlook in the euro area and its monetary policy strategy. In June 2014, the ECB started to conduct a series of targeted longer-term refinancing operations (TLTRO1) and also began to purchase asset-backed securities (ABSPP). The aim of TLTRO is to improve bank lending to households and non-financial corporations. In June 2016, a second series of targeted longer-term refinancing operations (TLTRO2) was launched by the ECB. The Asset-backed Securities Purchase Programme is limited to asset-backed securities that are eligible as collateral for Eurosystem refinancing operations, and secured by claims against non-financial sector entities. The ABSPP should help banks to diversify funding sources and to stimulate the issuance of new securities.

In January 2015, the ECB announced an expanded Asset Purchase Programme (APP), which initially consisted of the third Covered Purchase Programme, the Asset-Backed Securities Purchase Programme (ABSPP), and the Public Sector Asset Purchase Programme (PSPP). PSPP was introduced in March 2015 and consists of purchases of bonds issued by euro-area governments, agencies and European institutions. Under APP, the Eurosystem's monthly purchase has amounted to 60 billion euro since March 2015. APP should contribute to an increase of the inflation rate within the euro area. On March 2016, the ECB extended the Asset Purchase Programme. Since March 2016 the ECB has purchased 80 billion euro worth of securities every month. Furthermore, the Corporate Sector Purchase Programme (CSPP) was announced by the ECB as a fourth pillar of the APP. CSPP contains purchases of corporate bonds in the primary and secondary markets. Since June 2016 the monthly purchasing volume of investment grade euro-denominated bonds issued by non-bank corporations has totalled 10 billion euro.

\section{Transmission Channels}

In this section we discuss possible transmission channels through which nonstandard monetary policies conducted by the ECB influence prices of the selected financial assets in our countries of interest. The financial assets used in our event analysis are the following variables: a bilateral nominal exchange rate vis-à-vis the euro, yields of government bonds issued in local currencies, sovereign creditdefault swaps, an interbank interest rate, a benchmark stock market index and a corporate bond index. This selection of financial assets is broadly similar to the selection of variables employed by Takatas and Vela (2014) and Falagiarda et al. (2015). Takatas and Vela (2014) investigate the impact of the FED's policy on financial conditions in emerging markets economies. Falagiarda et al. (2015) examine whether the ECB's non-standard policy measures spilled over to noneuro area EU countries in Central and Eastern Europe. From a theoretical point of view, there are several possible transmission channels through which the ECB's non-standard monetary policies may spillover to non-euro small open advanced economies. In this section, we present the major transmission channels of international monetary policy spillovers. We suspect that both asset purchases 
(quantitative easing or credit easing) and forward guidance statements made by the ECB could exert spillover effects on financial variables through at least five channels: an exchange rate channel, the portfolio rebalancing channel, the signalling channel, the confidence channel and an international bank lending channel.

First, we elaborate on the exchange rate channel, through which conventional monetary policies and non-standard monetary policy announcements may affect our financial variables of interest. Standard monetary models imply that a decrease of the policy rate or, equivalently, an increase in the money supply in one country under a flexible exchange rate regime leads to a depreciation of the nominal spot exchange rate of its currency. This result is a consequence of Mundell's "Trilemma". Foreign monetary policy shocks will lead to an adjustment of the exchange rate in an economy with an open capital account if the domestic monetary authority doesn't response to the foreign monetary policy innovation. Unconventional monetary policies, like quantitative easing, are designed to influence long-term rates more directly. In principle, quantitative easing in a foreign country is associated with lower foreign long-term interest rates. Hence, it becomes more attractive for investors to invest in the domestic country. This adjustment of capital flows will result in an appreciation of the domestic currency. But the narrative is potentially more complex because a reduction of foreign longterm interest rates could also result in lower domestic long-term rates even if the domestic monetary authority does not adjust (Bernhard and Ebner 2016).

A second channel through which monetary policy spillovers may affect our countries of interest is the so-called portfolio rebalancing channel (Krishnamurthy and Vissing-Jorgensen 2011). At least two explanations of how this channel may affect foreign assets exist. First, the ECB's purchases of euro area government bonds would reduce the amount of these securities available to private investors. Thus, private investors are crowded out from this market segment by the ECB's asset purchases. In search of assets with a similar risk-return profile as the assets purchased by the ECB, private investors would move to close substitute assets. Substitute assets could include comparable domestic assets or assets in other countries. Hence, ECB purchases of government bonds may induce investors to rebalance their portfolio and this would lead to price changes of other financial assets. Second, in the standard portfolio balance model, the ECB's purchases of euro area government bonds would reduce their yields relative to comparable noneuro area bonds. Thus, foreign assets would get more attractive. Optimizing investors could turn to non-euro area assets for higher risk-adjusted returns. Higher demand for non-euro area bonds induces higher bond prices and thus lower bond yields. This channel could be a prominent channel of transmission of ECB announcements of SMP, PSPP and CSPP because these programs are characterized by the direct purchases of assets. These non-standard policies are designed to influence the prices and yields of domestic bonds directly.

Third, non-standard monetary policies may induce international spillover effects through the signalling channel (Krishnamurthy and Vissing-Jorgensen 2011, Falagiarda et al. 2015). The signalling channel is closely related to the portfolio rebalancing channel because it also operates via changes in the prices and 
yields of domestic financial assets. The signalling channel may work in the following way: if a central bank announces its intention to maintain lower shortterm interest rates for a longer period, market expectations for future interest rates may change. This could, through the expectations hypothesis of the term structure (Chinn 2013), lead to declining long-term interest rates. This results in changes in the interest rate differentials between economies across all maturities of bonds. Hence, this could influence financial variables in our selected economies. We expect that forward guidance may mainly operate via the signalling channel because the ECB sends signals about the future path of the main refinancing rate by using forward guidance.

The confidence channel could be a potential channel of transmission through which announcements of unconventional monetary policies may affect financial assets from small open advanced economies. Announcements of the ECB's nonstandard monetary policy measures could lead to both improved confidence and economic sentiment in the euro area. This could lead to a reprising of risks and capital outflows from Denmark, Norway and Sweden. Safe havens in particular could be affected by the confidence channel. Denmark, Norway and Sweden could be categorised as safe havens during the financial crisis (IMF 2013b). ECB announcements of unconventional monetary policy measures could lead to improved confidence in the euro area. This may lead to a higher demand for assets from the euro area and thus to capital outflows from our countries of interest. Capital outflows from our countries of interest should lead to lower asset prices and thus higher yields. The OMT announcements in particular might operate via the confidence channel because OMT reduced the perceived risk of euro area government bonds and has never been applied, yet.

The ECB's non-standard policy measures may also spillover via the international bank lending channel to other countries. Global financial integration potentially leads to a disruption of the transmission mechanism of conventional monetary policy (Hume and Sentence 2009). For instance, the rise in cross border financial flows could affect financial conditions in the domestic country. This also means that policy action taken by the ECB could have an impact on domestic credit conditions. An increase in liquidity in the euro area may have an impact on credit conditions in our countries of interest because of the presence of foreignowned banks in their local banking systems, which are controlled by parent banks located in the euro area. Hence, a decrease in the interbank rate available to the parent bank is associated with lower costs of funding for the subsidiary. However, it should be noted, that the costs of funding for the parent banks and subsidiaries are not perfectly correlated.

\section{Hypotheses}

In this section we discuss possible effects of the ECB's announcements of unconventional monetary policies on our selected financial assets. Based on the above mentioned international transmission channels, we can formulate specific expectations regarding the impact of ECB's unconventional monetary policies on 
selected financial assets from Denmark, Norway and Sweden. The formation of expected spillovers may facilitate the discussion of the empirical results, particularly with respect to the analysis of the systematic measures of ECB policies. However, our empirical set-up does not allow for an identification of individual international transmission channels of the ECB's non-standard monetary policy. So, we formulate hypotheses about how the announcements of the ECB's non-standard monetary policy measures affect financial assets from our countries of interest. Hence, we try to answer from a theoretical point of view what the overall effect of the ECB's UMP measures on financial assets from Denmark, Norway and Sweden could be.

Hypothesis 1: The net effect of the ECB's unconventional monetary policies on exchanges rates vis-à-vis the euro is ambiguous. Exchange rates vis-à-vis the euro could be affected by the ECB's non-standard policy measures via the exchange rate channel and the confidence channel. The exchange rate channel is especially important in the case of Sweden and Norway, given their flexible exchange rate regime and the high degree of financial and real integration of both economies with the euro area. As mentioned before, the impact of the exchange rate channel on exchange rates vis-à-vis the euro is negative and thus associated with an appreciation of the domestic currency. Hence, ECB announcements of unconventional monetary policies are associated with an appreciation of the Swedish krona and Norwegian krone and an upward pressure of the Danish krone. At the same time, the confidence channel should dampen the decrease of exchange rates vis-à-vis the euro because of raising confidence levels in the euro area.

Hypothesis 2: The net effect of the ECB's unconventional monetary policy measures on yields of Danish, Norwegian and Swedish government bonds is unclear. Given that government bonds from Denmark, Norway and Sweden are close substitutes for euro area sovereign bonds, announcements of non-standard policy measures by the ECB may affect government bond yields in our countries of interest via the portfolio rebalancing channel. We expect that the effect of the portfolio rebalancing channel on government bond yields in our selected countries is negative. The signalling channel also implies a decrease of yields of government bonds from our countries of interest. As discussed earlier, ECB announcements of non-standard monetary policy measures could boost both confidence levels and economic sentiment in the euro area. This could lead to capital outflows from safe haven countries. Denmark, Norway and Sweden can be classified as safe haven countries (IMF 2013b). Capital outflows from these countries induced by the ECB's UMP measures are associated with increasing yields of government bonds from our countries of interest. Furthermore, the exchange rate channel implies an appreciation of the respective currency against the euro. This effect will make Danish, Norwegian and Swedish bonds more expensive for foreign investors. Thus, demand for these bonds will decrease. Hence, an appreciation of the respective currency is associated with increasing yields of government bonds.

Hypothesis 3: Ex ante, the net effect of the ECB's unconventional monetary policies on the prices of non-euro area corporate bonds is ambiguous. In principle, corporate bonds from Denmark, Norway and Sweden could be affected by the ECB's non-standard policy measures via the portfolio rebalancing channel. Yields 
of corporate bonds from Denmark, Norway and Sweden will be affected modestly by ECB UMP measures via the portfolio rebalancing channel if non-standard monetary policy measures only contain purchases of euro area government bonds. Only ECB purchases of euro area corporate bonds would have a visible impact on corporate bond yields in our countries of interest. If the ECB buys only euro area sovereign bonds, yields of corporate bonds from our countries of interest will be mostly unaffected because only a few corporate bond segments from our countries of interest could be considered as close substitutes for euro area government bonds. In principle, the portfolio rebalancing channel implies that the yields of corporate bonds from our countries of interest will decline. Whether the signalling channel could be considered as an important channel in explaining price reactions of foreign corporate bonds depends on whether the prices of euro area corporate bonds react to ECB announcements to keep short-term interest rates down for a longer period. If euro area corporate bonds react to the ECB's commitment to maintain lower interest rates in the future, this will lead to spillovers similar to that mentioned before in the case of the portfolio rebalancing channel. The confidence channel implies that the yields of corporate bonds from our countries of interest may increase. The exchange rate channel also implies increasing corporate bond yields in Denmark, Norway and Sweden due to the related appreciation of the respective domestic currency against the euro.

Hypothesis 4: The net effect of the ECB's non-standard monetary policy measures on CDS spreads in our countries of interest is ambiguous. CDS spreads in our countries of interest could be indirectly affected by the ECB's UMP measures. As mentioned before, the ECB's purchases of euro area government bonds may result in lower yields of sovereign bonds from non-euro area countries if the portfolio rebalancing channel or the signalling channel is at play. Lower yields of government bonds from Denmark, Norway and Sweden may imply an improved debt liability of the respective country. This could result in an improved debt sustainability of these countries. Hence, the probability of default of government bonds from our countries of interest may fall. This process could result in declining CDS spreads in non-euro area countries. If yields of non-euro area government bonds increase due to non-standard monetary policy measures of the ECB, CDS spreads in non-euro area countries will increase. This could be the case if both the confidence channel and the exchange rate channel are the main driver of spillover effects.

Hypothesis 5: The ECB's unconventional monetary policy measures will induce decreasing interbank rates in our countries of interest. The ECB's unconventional monetary policies may affect interbank rates in our countries of interest via the international bank lending channel. A reduction of the interbank rate in the euro area induced by an increase in liquidity may result in a lower demand at the local money market if the presence of foreign-owned banks in the local banking is large enough (Falagiarda et al. 2015). Lower demand at the domestic money markets will lead to declining interbank rates in Denmark, Norway and Sweden.

Hypothesis 6: The net effect of the ECB's non-standard monetary policy measures on equity prices in our countries of interest is ambiguous. Equity prices 
in our countries should be negatively affected by non-standard policy measures conducted by the ECB via the confidence channel and the exchange rate channel, respectively. First, the confidence channel implies a negative impact on equity prices in Denmark, Norway and Sweden. The ECB's non-standard monetary policy measures could lead to both improved confidence and economic outlook in the euro area and thus, ceteris paribus, risky assets from the euro area get more attractive relative to risky assets from our countries of interest. Moreover, improved confidence and economic sentiment in the euro area may be associated with higher expected dividends of euro area equities. Hence, ceteris paribus, euro area equities get more attractive relative to equities from our selected countries. Second, the exchange rate channel induces lower equity prices in our countries of interest. An appreciation of the domestic currency against the euro induced by the ECB's unconventional monetary policies leads to higher equity prices for foreign investors. This results in a lower demand for Danish, Norwegian and Swedish equities and hence lower equity prices. Furthermore, an appreciation of the respective domestic currency against the euro is associated with a reduction of competitiveness of internationally exposed firms. Hence, an appreciation of the respective currency against the euro should weigh on the equity prices of these firms. Though, more available liquidity and lower discount rate expectations due to the ECB's expansionary unconventional monetary policy measures should lead to higher equity prices in non-euro area countries (Bernhard and Ebner 2016).

\section{Event Study Methodology and Empirical Results}

\section{Event Study Methodology}

Our event study analysis, through which we try to detect the spillovers from the ECB's unconventional monetary policies, uses the ordinary least squares estimation. We use Newey-West adjusted standard errors because we have detected autocorrelation by conducting Breusch Pagan LM tests. The Newey-West standard errors are computed by using a non-pre-whitened Bartlett Kernell with a specified bandwidth of eleven. Note, that the bandwidth is equal to one plus the truncation parameter $m=0.75 T^{1 / 3}$, where $T$ represents the included observations. In our regression without controlling for the extent of monetary policy surprise, we estimate the following country specific equation using daily data from 01.01.2008 to 20.05.2016:

$$
\begin{aligned}
& \Delta X_{t}=\alpha+\beta_{1} \Delta I R_{t}^{D o m}+\beta_{2} \Delta I R_{t}^{E C B}+\beta_{3} N S M P_{t}^{D o m}+\delta N S M P_{t}^{E C B}+\gamma N S M P_{t}^{U S}+\beta_{4} \Delta V I X_{t}+ \\
& \beta_{5} \Delta T E D_{t}+\beta_{6} \Delta E U D S_{t}+\varepsilon_{t}
\end{aligned}
$$

where $X_{t}$ is our dependent variable of interest and it represents the change in the following asset prices: the main equity price index, the exchange rate vis-à-vis the euro, medium- and long-term government bond yields, the 3-month interbank rate, 5- and 10-year CDS spreads and the S\&P corporate bond index. The variable 
$I R_{t}^{\text {Dom }}$ reflects the domestic central bank policy rate and $I R_{t}^{E C B}$ stands for the ECB policy rate. The vector $N S M P_{t}^{\text {Dom }}$ is a country specific dummy and contains the announcements of unconventional monetary policies released by the domestic monetary policy authority. $N S M P_{t}^{E C B}$ is our independent variable of interest. This vector is an event-dummy associated with the ECB's announcements of nonstandard monetary policy measures. The event list used in our empirical analysis is based on the list of Falagiarda et al. (2015) and a thorough investigation of statements issued by the ECB. Here we use press conferences and press releases published by the ECB. By including $N S M P_{t}^{U S}$ we control for spillover effects from the FED's announcements of non-standard monetary policies on financial assets from Denmark, Norway and Sweden. The variable VIX is the volatility index for the euro area. With this variable we control for financial turmoil in euro area financial markets. The variable $T E D_{t}$ reflects the ted spread. The ted spread is calculated as the three-month LIBOR rate less the US Treasury bill rate. We control for perceived credit risk in the global economy by including the ted spread in our baseline regressions. The variable $E U D S_{t}$ is the total stock market index for the EU and it controls for market-wide business climate changes in the EU. Furthermore, we introduce two interaction terms in our regression as control variables (Falagiarda et al. 2015). With the first interaction term we control for occasions when the ECB and domestic central banks implemented changes of the policy rates on the same day. Through the inclusion of the second interaction term we control for events when the ECB and domestic central banks adopted nonstandard monetary policy measures on the same day. With the inclusion of these interaction terms, we address the problem of policy endogeneity (Falagiarda et al. 2015).

Furthermore, we estimate our baseline specification relying on a market-based measure of monetary policy surprise. In order to measure the surprise component of the ECB's policy announcements, we interact to our event-dummy associated with ECB announcements of non-standard monetary policy measures with a quantitative measure of monetary policy surprise. Hence, we also estimate the following country specific equation using daily data from 01.01.2008 to 20.05.2016:

$$
\begin{aligned}
& \Delta X_{t}=\alpha+\beta_{1} \Delta I R_{t}^{D o m}+\beta_{2} \Delta I R_{t}^{E C B}+\beta_{3} N S M P_{t}^{D o m}+\delta N S M P_{t}^{E C B} \Delta s_{t}+\gamma N S M P_{t}^{U S}+\beta_{4} \Delta V I X_{t}+ \\
& \beta_{5} \Delta T E D_{t}+\beta_{6} \Delta E U D S_{t}+\varepsilon_{t}
\end{aligned}
$$

where $\Delta s_{t}$ reflects different quantitative measures of monetary policy surprise. In our baseline specification we use the change in longer-term government bond futures (Bernhard and Ebner 2016). Following Bernhard and Ebner (2016), we use the change in 10-year German Bund futures as a market-based measure of monetary policy surprise. An increase in the price of the 10-year German Bund future could be interpreted as a more expansionary monetary policy of the ECB than expected by financial markets. The financial variables used in our regressions 
are defined as follows: the bilateral exchange rate vis-à-vis the euro, the CDS spreads, the stock market indices and the VIX volatility index are expressed as daily percentage changes. The monetary policy rate, the interbank interest rate, government bond yields are expressed as daily percentage point changes. The $\mathrm{S} \& \mathrm{P}$ corporate bond index is defined as daily basis point changes. For the event dummies we use one-day event windows. It seems that international spillovers are likely to have a longer transmission lag compared to the transmission lag of domestically implemented monetary policy to domestic variables (Bernhard and Ebner 2016). Hence, it is justified that we use daily data in order to investigate the impact of the ECB's unconventional monetary policies on financial variables from Denmark, Norway and Sweden.

\section{Spillovers of ECB's Unconventional Monetary Policies}

At first, we discuss the results of our regressions without controlling for monetary policy surprise. Hence, we use the binary dummy variable without interacting it with a market surprise measure. We find spillover effects on financial variables from Denmark, Norway and Sweden. However, our results in Table 1 suggest that only few financial assets were affected by ECB's announcements of non-standard policy measures.

Table 1. Impact of ECB's Announcements of Unconventional Monetary Policy Measures (Regression without Surprise, All Events)

\begin{tabular}{|l|c|c|c|}
\hline \multirow{2}{*}{ Benchmark bond yield (10 y) } & \multicolumn{3}{|c|}{ ECB's Non-standard Monetary Policies } \\
\cline { 2 - 4 } & Sweden & Denmark & Norway \\
\cline { 2 - 4 } & 0.0058 & 0.0020 & $0.0149^{* *}$ \\
\hline \multirow{2}{*}{ Benchmark bond yield (5 y) } & -0.0027 & $-0.0068)$ & $(0.0066)$ \\
\cline { 2 - 4 } & $(0.0062)$ & $(0.0072)$ & 0.0133 \\
\hline \multirow{2}{*}{ Benchmark bond yield (2/3 y) } & -0.0069 & -0.0028 & $(0.0083)$ \\
\cline { 2 - 4 } & $(0.0060)$ & $(0.0081)$ & 0.0062 \\
\hline \multirow{2}{*}{ CDS 10-year (USD) } & 0.0042 & $-0.0203^{* *}$ & $(0.0074)$ \\
\cline { 2 - 4 } & $(0.0107)$ & $(0.0087)$ & -0.0028 \\
\hline \multirow{2}{*}{ CDS 5-year (USD) } & 0.0011 & $-0.0211^{* * *}$ & $(0.0027)$ \\
\cline { 2 - 4 } & $(-0.0097)$ & $(0.0776)$ & -0.0015 \\
\hline \multirow{2}{*}{ Interbank rate (3 M) } & -0.0063 & -0.0004 & $(0.0038)$ \\
\cline { 2 - 4 } & $(0.0075)$ & $(0.0035)$ & 0.0033 \\
\hline \multirow{2}{*}{ Exchange Rate } & -0.0002 & 0.0000 & $(0.0151)$ \\
\cline { 2 - 4 } & $(0.0006)$ & $(0.0000)$ & 0.0004 \\
\hline \multirow{2}{*}{ Stock market index } & $-0.0018^{*}$ & -0.0014 & $(0.0008)$ \\
\cline { 2 - 4 } & $(0.0010)$ & $(0.0011)$ & -0.0021 \\
\hline \multirow{2}{*}{ S\&P Corporate bond index } & 0.0051 & -0.0612 & $-0.0019)$ \\
\cline { 2 - 4 } & $(0.0191)$ & $(0.0459)$ & $(0.0277)$ \\
\hline
\end{tabular}

Note: Newey-West standard errors in parentheses. $* * *, * *$ and $*$ display significance at the $1 \%, 5 \%$ and $10 \%$ level, respectively. 
Announcements of the ECB's unconventional monetary policies were associated with increasing long-term government bond yields in Norway. Thus, the confidence channel could be a prominent channel in explaining the impact of ECB announcements of non-standard measures on 10-year government bond yields from Norway. As mentioned before, the ECB's announcements of UMP measures could operate via the confidence channel. The announcement of ECB programs could lead to improved confidence in the euro area. The return of confidence should be associated with capital outflows from Denmark, Norway and Sweden and hence with increasing government bond yields. It seems that this was the case in Norway because Norwegian 10-year sovereign bond yields increased due to the ECB's announcements of non-standard policy measures.

Moreover, announcements of the ECB's UMP measures were associated with declining CDS spreads in Denmark. Both the Danish 5- and 10-year CDS spreads were affected by the ECB's announcements of non-standard policy measures. Furthermore, the Swedish benchmark stock market index was negatively affected by ECB announcements. In addition, the Norwegian S\&P corporate bond index was negatively influenced by announcements of the ECB's UMP measures. Thus, it seems that both the Swedish stock market index and the Norwegian S\&P corporate bond index were mainly affected by the confidence channel.

We find that the exchange rates of Nordic currencies vis-à-vis the euro were not affected by ECB announcements. Furthermore, we find no impact of ECB announcements of UMP measures on interbank rates in Denmark, Norway and Sweden. Similarly, medium-term government bonds in our countries of interest were not influenced by announcements of the ECB's non-standard policy measures.

Next, we discuss the empirical results of our estimations when controlling for monetary policy surprise. Here, we rely on the daily change in 10-year German Bund futures as a measure for monetary policy surprise. Our results in Table 2 show that significantly more financial variables were affected by the ECB announcements than in our regressions without controlling for monetary policy surprise. Hence, we confirm the result of Bernhard and Ebner (2016), who find that only unexpected changes of monetary policy had a systematic impact on Swiss asset prices. Moreover, our results change considerably when we interact our dummy with the daily change in 10-year German bund futures.

We find that medium- and long-term government bond yields were significantly influenced by surprising ECB announcements of non-standard policy measures. Furthermore, our results suggest that expansionary surprises led to decreasing sovereign bond yields in Denmark, Norway and Sweden. Hence, it seems that surprising ECB announcements of UMP measures could mainly operate via the portfolio rebalancing channel and the signalling channel. Thus, Danish, Norwegian and Swedish government bonds tend to be adequate substitutes for euro area sovereign bonds. 
Table 2. Impact of ECB's Announcements of Unconventional Monetary Policy Measures (Regression with Surprise, All Events)

\begin{tabular}{|l|c|c|c|}
\hline \multirow{2}{*}{ Benchmark bond yield (10 y) } & \multicolumn{3}{|c|}{ ECB's Non-standard Monetary Policies } \\
\cline { 2 - 4 } & Sweden & Denmark & Norway \\
\cline { 2 - 4 } & $-0.0244 * * *$ & $-0.0347 * * *$ & $-0.0196 * * *$ \\
\hline \multirow{2}{*}{ Benchmark bond yield (5 y) } & $-0.0227 * * *$ & $-0.0213 * * *$ & $-0.0222^{* * *}$ \\
\cline { 2 - 4 } & $(0.0041)$ & $(0.0053)$ & $(0.0048)$ \\
\hline \multirow{2}{*}{ Benchmark bond yield (2/3 y) } & $-0.0160 * * *$ & $-0.0279 * * *$ & $-0.0167 * * *$ \\
\cline { 2 - 4 } & $(0.0034)$ & $(0.0059)$ & $(0.0042)$ \\
\hline \multirow{2}{*}{ CDS 10-year (USD) } & 0.0054 & $0.0209 * *$ & 0.0008 \\
\cline { 2 - 4 } & $(0.0068)$ & $(0.0081)$ & $(0.0017)$ \\
\hline \multirow{2}{*}{ CDS 5-year (USD) } & 0.0047 & $0.0154 * *$ & 0.0005 \\
\cline { 2 - 4 } & $(0.0061)$ & $(0.0070)$ & $(0.0021)$ \\
\hline \multirow{2}{*}{ Interbank rate (3 M) } & 0.0035 & 0.0008 & $0.0148 * *$ \\
\cline { 2 - 4 } & $(0.0052)$ & $(0.0025)$ & $(0.0067)$ \\
\hline \multirow{2}{*}{ Exchange Rate } & -0.0004 & 0.0000 & -0.0007 \\
\cline { 2 - 4 } & $(0.0005)$ & $(0.0000)$ & $(0.0005)$ \\
\hline \multirow{2}{*}{ Stock market index } & 0.0011 & 0.0001 & -0.0003 \\
\hline \multirow{2}{*}{ S\&P Corporate bond index } & $(0.0009)$ & $(0.0012)$ & $(0.0013)$ \\
\cline { 2 - 4 } & $0.0568 * * *$ & $0.2038 * * *$ & $0.1150 * * *$ \\
\hline
\end{tabular}

Note: Newey-West standard errors in parentheses. $* * *, * *$ and $*$ display significance at the $1 \%, 5 \%$ and $10 \%$ level, respectively.

Moreover, we show that a positive surprise stemming from ECB announcements was associated with increasing corporate bond indices in our countries of interest. Hence, declining medium- and long-term government bond yields transmitted to corporate bond yields. However, our results may also suggest that corporate bonds from Denmark, Norway and Sweden were affected by surprising ECB UMP measures via the portfolio rebalancing channel. Furthermore, we find that CDS spreads in Denmark were significantly influenced by our monetary surprise variable. Our results show that ECB announcements led to increasing CDS spreads in Denmark, which is at odds with our theoretical considerations. As mentioned before, the ECB's announcements should affect CDS spreads indirectly via their impact on government bond yields. We have argued that declining sovereign bond yields due to the ECB's announcements of non-standard policy measures may lead to decreasing CDS spreads because lower yields of government bonds could imply an improved debt liability of a country. Our results also show that CDS spreads in Norway and Sweden were not affected by surprising ECB announcements of unconventional monetary policies.

In addition, we find that the ECB's announcements of non-standard policy measures had a positive statistically significant impact on the 3-month money market rate in Norway. Hence, this result stands in contradiction to the impact of 
the international bank lending channel on the 3-month interest rate. We have argued before, that the ECB's announcements should lead to increasing 3-month interbank rates in Denmark, Norway and Sweden via the international bank lending channel. Furthermore, we find no impact of ECB announcements on the 3month money market rates in Denmark and Sweden, respectively. We find that the exchange rates of Nordic currencies vis-à-vis the euro were not affected by the ECB announcements. All coefficients are not statistically significant. Moreover, benchmark stock indices in Denmark, Norway and Sweden were not influenced by the ECB's non-standard policy measures.

\section{Spillovers of Systematic Unconventional Monetary Policies}

In this section we study the impact of systematic measures of the ECB's unconventional monetary policies on our selected financial variables. During the last number of years, the ECB announced and implemented various unconventional monetary policy measures. Each non-standard measure had different objectives and thus could result in qualitatively and quantitatively different monetary spillover effects to our selected countries (Falagiarda et al. 2015). In particular, we investigate the impact of the ECB's announcements related to SMP, OMT, FWG, PSPP and CSPP on financial variables from Denmark, Norway and Sweden. Hence, we estimate our baseline specification over the whole sample with systemized $N S M P_{t}^{E C B}$ variables.

The results in Table 3 show that SMP announcements exert the strongest impact on financial variables from Norway. Almost all selected Norwegian financial assets were statistically significantly affected by announcements related to SMP. In contrast, SMP announcements had only modest effects on financial assets from Sweden. Moreover, our results indicate that cross-country heterogeneity exists. For instance, we find that SMP announcements were associated with declining government bond yields in Denmark, whereas Norwegian government bond yields increased due to SMP announcements.

Our results in Table 3 show that events related to SMP announcements influenced sovereign bond yields in Denmark and Norway, respectively. Whereas Swedish government bonds were not affected by SMP announcements. Our results suggest that in the case of Danish 5- and 10-year government bonds, the portfolio rebalancing channel outweighed the impact of the confidence channel and the exchange rate channel. Hence, SMP announcements led to declining 5- and 10year government bond yields in Denmark. In contrast to that, SMP announcements were associated with increasing 5- and 10-year government bond yields in Norway. Hence, the impact of the portfolio rebalancing channel was offset by the effects of the confidence channel and exchange rate channel on Norwegian sovereign bond yields. 
Table 3. Impact of ECB's Announcements of Unconventional Monetary Policy Measures (Regression without Surprise, SMP)

\begin{tabular}{|l|c|c|c|}
\hline \multirow{2}{*}{ Benchmark bond yield (10 y) } & \multicolumn{3}{|c|}{ SMP } \\
\cline { 2 - 4 } & Sweden & Denmark & Norway \\
\cline { 2 - 4 } & 0.0501 & $-0.0451^{* * *}$ & $0.1104^{* * *}$ \\
\hline \multirow{2}{*}{ Benchmark bond yield (5 y) } & $0.0338)$ & $(0.0059)$ & $(0.0198)$ \\
\cline { 2 - 4 } & $(0.0380)$ & $-0.0339^{* * *}$ & $0.0853^{* * *}$ \\
\hline \multirow{2}{*}{ Benchmark bond yield (2/3 y) } & -0.0233 & -0.0140 & $(0.0093)$ \\
\cline { 2 - 4 } & $(0.0437)$ & $(0.0184)$ & 0.0148 \\
\hline \multirow{2}{*}{ CDS 10-year (USD) } & 0.0064 & $-0.0312^{*}$ & $-0.0173)$ \\
\cline { 2 - 4 } & $(0.0529)$ & $(0.0166)$ & $(0.0063)$ \\
\hline \multirow{2}{*}{ CDS 5-year (USD) } & 0.0040 & $-0.0417^{* *}$ & -0.0133 \\
\cline { 2 - 4 } & $(0.0649)$ & $(0.0162)$ & $(0.0100)$ \\
\hline \multirow{2}{*}{ Interbank rate (3 M) } & 0.0220 & -0.0013 & $0.0777^{* * *}$ \\
\cline { 2 - 4 } & $(0.0136)$ & $(0.0039)$ & $(0.0210)$ \\
\cline { 2 - 4 } Exchange Rate & -0.0057 & 0.0000 & $-0.0049^{* * *}$ \\
\cline { 2 - 4 } & $(0.0041)$ & $(0.0001)$ & $(0.0010)$ \\
\cline { 2 - 4 } Stock market index & $-0.0089^{* * * *}$ & 0.0045 & $-0.0137 * * *$ \\
\hline \multirow{2}{*}{ S\&P Corporate bond index } & $(0.0012)$ & $(0.0037)$ & $(0.0007)$ \\
\cline { 2 - 4 } & $0.1226^{*}$ & $0.2983^{* *}$ & $-0.1526^{* * *}$ \\
\hline \multirow{2}{*}{ Note: Newey-West standard errors } & $(0.0733)$ & $(0.1470)$ & $(0.0581)$ \\
\hline
\end{tabular}

Note: Newey-West standard errors in parentheses. $* * *, * *$ and $*$ display significance at the $1 \%, 5 \%$ and $10 \%$ level, respectively.

Furthermore, SMP announcements had a significant impact on CDS spreads in Denmark and Norway. SMP announcements led to decreasing CDS spreads in Denmark and Norway. Hence, declining government bond yields transmitted to decreasing CDS spreads in the case of Denmark but not in the case of Norway. SMP related announcements increased the Danish S\&P corporate bond index whereas the Norwegian S\&P corporate bond index decreased due to SMP announcements. Hence, declining government bond yields transmitted to decreasing corporate bond yields in Denmark. In the case of Norway, increasing sovereign bond yields resulted in rising corporate bond yields. Moreover, our results suggest that the Swedish S\&P corporate bond index was not affected by SMP announcements. Furthermore, we find that SMP announcements appreciated the Norwegian krone against the euro. This result confirms our notion that the ECB's unconventional monetary policy measures were associated with appreciations of local currencies vis-à-vis the euro. However, we find no impact of SMP announcements on exchange rates vis-à-vis the euro in Denmark and Sweden.

Benchmark stock market indices were negatively affected by SMP announcements in Sweden and Norway. Hence, the negative response of Norwegian and Swedish equity prices suggest that in both countries the confidence channel and the exchange rate channel outweighed the positive impact of the portfolio rebalancing channel. We find no statistically significant effect of SMP-related announcements on the Danish benchmark stock market index. 
Moreover, we find that SMP announcements led to an increase of the 3-month interest rate in Norway. Our results also suggest that the 3-month interbank rate was not affected by SMP announcements in Denmark and Sweden, respectively.

Table 4. Impact of ECB's Announcements of Unconventional Monetary Policy Measures (Regression without Surprise, OMT)

\begin{tabular}{|l|c|c|c|}
\hline \multirow{2}{*}{ Benchmark bond yield (10 y) } & \multicolumn{2}{|c|}{ OMT } \\
\cline { 2 - 4 } & Sweden & Denmark & Norway \\
\cline { 2 - 4 } & -0.0186 & -0.0064 & -0.0136 \\
\hline \multirow{2}{*}{ Benchmark bond yield (5 y) } & -0.0152 & 0.0084 & $(0.0088)$ \\
\cline { 2 - 4 } & $(0.0257)$ & $(0.0144)$ & $-0.0316^{*}$ \\
\hline \multirow{2}{*}{ Benchmark bond yield (2/3 y) } & -0.0155 & 0.0015 & $(0.0183)$ \\
\cline { 2 - 4 } & $(0.0178)$ & $(0.0212)$ & $-0.0224^{* *}$ \\
\hline \multirow{2}{*}{ CDS 10-year (USD) } & 0.0004 & -0.0079 & $(0.0092)$ \\
\cline { 2 - 4 } & $(0.0056)$ & $(0.0093)$ & -0.0114 \\
\hline \multirow{2}{*}{ CDS 5-year (USD) } & -0.0014 & -0.0102 & $(0.0070)$ \\
\cline { 2 - 4 } & $(0.0079)$ & $(0.0122)$ & 0.0018 \\
\hline \multirow{2}{*}{ Interbank rate (3 M) } & $0.0556^{* * *}$ & 0.0030 & $(0.0116)$ \\
\cline { 2 - 4 } & $(0.0142)$ & $(0.0026)$ & -0.0024 \\
\hline \multirow{2}{*}{ Exchange Rate } & 0.0004 & 0.0001 & $(0.0134)$ \\
\cline { 2 - 4 } & $(0.0020)$ & $(0.0001)$ & $0.0076^{* * *}$ \\
\hline \multirow{2}{*}{ Stock market index } & -0.0067 & $-0.0052^{*}$ & $(0.0022)$ \\
\cline { 2 - 4 } & $(0.0042)$ & $(0.0032)$ & $-0.0077^{* *}$ \\
\hline \multirow{2}{*}{ S\&P Corporate bond index } & $0.0773^{* *}$ & 0.0393 & $(0.0038)$ \\
\cline { 2 - 4 } & $(0.0349)$ & $(0.0665)$ & 0.0506 \\
\hline
\end{tabular}

Note: Newey-West standard errors in parentheses. ${ }^{* * *}, * *$ and $*$ display significance at the $1 \%, 5 \%$ and $10 \%$ level, respectively.

The empirical results reported in Table 4 indicate that announcements related to OMT exerted weak spillover effects on financial assets from Denmark, Norway and Sweden. Few financial variables were statistically significantly influenced by OMT announcements. In particular, we find that medium-term government bond yields were negatively affected by OMT announcements in Norway. It was expected that OMT announcements should lead to rising sovereign bond yields in Denmark, Norway and Sweden. However, our results indicate the opposite, namely that OMT announcements led to declining medium-term sovereign yields in Norway. Thus, it could be that the portfolio channel and signalling channel outweighed the negative impact of the confidence channel on government bond yields. Nevertheless, our results indicate that the confidence channel was not a prominent channel in explaining how OMT announcements spilled over to Norwegian medium-term government bonds.

As expected, OMT announcements led to a depreciation of local currencies vis-à-vis the euro. However, only the Norwegian krone was statistically 
significantly affected by OMT announcements. Moreover, we find that OMT announcements led to decreasing equity prices in Denmark and Norway. Hence, we conclude that the Danish and Norwegian benchmark stock market indices were influenced by OMT announcements mainly via the confidence channel. Furthermore, we conclude that in the case of Norwegian equities, the confidence channel outweighed the positive impact of the depreciation of the Norwegian krone. We also find that OMT-related announcements affected the Swedish S\&P corporate bond index positively. Moreover, OMT announcements increased the 3month interbank rate in Sweden

Table 5. Impact of ECB's Announcements of Unconventional Monetary Policy Measures (Regression without Surprise, PSPP)

\begin{tabular}{|l|c|c|c|}
\hline \multirow{2}{*}{ Benchmark bond yield (10 y) } & \multicolumn{3}{|c|}{ PSPP } \\
\cline { 2 - 4 } & Sweden & Denmark & Norway \\
\cline { 2 - 4 } & -0.0142 & $-0.0337 * *$ & -0.0226 \\
\hline \multirow{2}{*}{ Benchmark bond yield (5 y) } & $-0.0120)$ & $(-0.0159)$ & $(0.0185)$ \\
\cline { 2 - 4 } & $(0.0075)$ & -0.0160 & -0.0077 \\
\hline \multirow{2}{*}{ Benchmark bond yield (2/3 y) } & 0.0023 & $-0.0117)$ & $(0.0155)$ \\
\cline { 2 - 4 } & $(0.0040)$ & $(0.0159)$ & -0.0053 \\
\hline \multirow{2}{*}{ CDS 10-year (USD) } & 0.0004 & 0.0278 & $(0.0116)$ \\
\cline { 2 - 4 } & $(0.0023)$ & $(0.0230)$ & -0.0005 \\
\hline \multirow{2}{*}{ CDS 5-year (USD) } & 0.0015 & 0.0149 & $-0.0017)$ \\
\cline { 2 - 4 } & $(0.0025)$ & $(0.0213)$ & $(0.0030)$ \\
\hline \multirow{2}{*}{ Interbank rate (3 M) } & 0.0027 & $0.0113 * * *$ & 0.0016 \\
\cline { 2 - 4 } & $(0.0121)$ & $(0.0030)$ & $(0.0054)$ \\
\hline \multirow{2}{*}{ Exchange Rate } & -0.0013 & 0.0001 & 0.0021 \\
\cline { 2 - 4 } & $(0.0015)$ & $(0.0002)$ & $(0.0015)$ \\
\hline \multirow{2}{*}{ Stock market index } & -0.0012 & -0.0006 & -0.0003 \\
\cline { 2 - 4 } & $(0.0036)$ & $(0.0027)$ & $(0.0056)$ \\
\hline \multirow{2}{*}{ S\&P Corporate bond index } & 0.0078 & $-0.0509 *$ & 0.0514 \\
\cline { 2 - 4 } & $(0.0230)$ & $(0.0281)$ & $(0.0600)$ \\
\hline
\end{tabular}

Note: Newey-West standard errors in parentheses. $* * *, * *$ and $*$ display significance at the $1 \%, 5 \%$ and $10 \%$ level, respectively.

PSPP announcements resulted in limited spillover effects on financial assets from Denmark, Norway and Sweden (see Table 5). In the case of Norway and Sweden, no statistically significant coefficient has been found. Events related to the announcements regarding PSPP resulted in limited spillover effects on financial variables from Denmark. We find that PSPP announcements decreased long-term government bond yields in Denmark. Hence, Danish long-term government bond yields were mainly affected by PSPP announcements via the portfolio rebalancing channel. Moreover, our results in Table 5 suggest that PSPP announcements decreased the Danish S\&P corporate bond index. We also show 
that PSPP announcements were associated with an increase of the 3-month interest rate in Denmark.

Table 6. Impact of ECB's Announcements of Unconventional Monetary Policy Measures (Regression without Surprise, CSPP)

\begin{tabular}{|l|c|c|c|}
\hline \multirow{2}{*}{ Benchmark bond yield (10 y) } & \multicolumn{3}{|c|}{ CSPP } \\
\cline { 2 - 4 } & Sweden & Denmark & Norway \\
\cline { 2 - 4 } & $0.0518^{*}$ & $0.0703^{* * *}$ & 0.0270 \\
\hline \multirow{2}{*}{ Benchmark bond yield (5 y) } & $0.0360^{* * *}$ & $(0.0148)$ & $(0.0269)$ \\
\cline { 2 - 4 } & $(0.0112)$ & $(0.0172)$ & $(-0.01250)$ \\
\hline \multirow{2}{*}{ Benchmark bond yield (2/3 y) } & $0.0294^{* *}$ & $0.0634^{* * *}$ & $0.0106^{*}$ \\
\cline { 2 - 4 } & $(0.0123)$ & $(0.0196)$ & $(0.0055)$ \\
\hline \multirow{2}{*}{ CDS 10-year (USD) } & -0.1571 & -0.1160 & $-0.0022^{* *}$ \\
\cline { 2 - 4 } & $(0.1124)$ & $(0.0855)$ & $(0.0010)$ \\
\hline \multirow{2}{*}{ CDS 5-year (USD) } & -0.1130 & -0.0823 & -0.0022 \\
\cline { 2 - 4 } & $(0.0807)$ & $(0.0620)$ & $(0.0014)$ \\
\hline \multirow{2}{*}{ Interbank rate (3 M) } & 0.0200 & -0.0063 & $0.0158^{* * *}$ \\
\cline { 2 - 4 } & $(0.0176)$ & $(0.0067)$ & $(0.0034)$ \\
\hline \multirow{2}{*}{ Exchange Rate } & 0.0006 & $-0.0003 * * *$ & $-0.0077 * * *$ \\
\hline \multirow{2}{*}{ Stock market index } & $(0.0021)$ & $(0.0000)$ & $(0.0025)$ \\
\hline \multirow{2}{*}{ S\&P Corporate bond index } & $-0.0048^{* *}$ & 0.0029 & 0.0057 \\
\cline { 2 - 4 } & $(0.0021)$ & $(0.0069)$ & $(0.0040)$ \\
\cline { 2 - 4 } & -0.0779 & $-0.6789 * * *$ & $-0.2061^{* *}$ \\
\hline
\end{tabular}

Note: Newey-West standard errors in parentheses. ${ }^{* * *}, * *$ and $*$ display significance at the $1 \%, 5 \%$ and $10 \%$ level, respectively.

CSPP announcements affected sovereign bond yields in Denmark, Norway and Sweden. Our results in Table 6 suggest however that long-term government bond yields in Norway were not influenced by CSPP announcements. In contrast to PSPP announcements, announcements related to CSPP led to rising mediumand long-term government bond yields. Hence, the response of government bond yields to CSPP announcements suggest that the exchange rate channel and confidence channel outweighed the impact on sovereign bond yields through the portfolio rebalancing channel and signalling channel. Moreover, we find that increasing government bond yields transmitted to declining S\&P corporate bond indices in Denmark and Norway. Hence, this transmission channel outweighed the effect on corporate bond yields via the portfolio rebalancing channel.

Furthermore, CSPP announcements were associated with declining benchmark stock market indices in Denmark and Norway. Thus, it seems that CSPP announcements spilled over to Danish and Norwegian equities mainly via the confidence channel and exchange rate channel. It seems that CSPP announcements led to improved confidence and economic sentiment in the euro area and hence to 
declining equity prices in Denmark and Norway. Furthermore, it seems that the exchange rate channel induced lower equity prices in Denmark and Norway as in our findings CSPP announcements were associated with decreasing exchange rates in Denmark and Norway. As mentioned before, appreciation of the local currencies vis-à-vis the euro is associated with declining domestic equity prices. We also find that CSPP announcements influenced CDS spreads in Norway and affected the three-month interbank rate in Norway.

So far, we have analysed the international spillover effects of the ECB's unconventional monetary policy measures associated with asset purchases. Now, we turn to the effects of the ECB's forward guidance on financial assets from Denmark, Norway and Sweden. Forward guidance is not associated with the purchases of assets. With forward guidance, the ECB specifies the future path of short-term interest rates. Hence, we expect that FWG announcements mainly operated via the signalling channel.

Table 7. Impact of ECB's Announcements of Unconventional Monetary Policy Measures (Regression without Surprise, FWG Statements)

\begin{tabular}{|l|c|c|c|}
\hline \multirow{2}{*}{ Benchmark bond yield (10 y) } & \multicolumn{3}{|c|}{ FWG } \\
\cline { 2 - 4 } & Sweden & Denmark & Norway \\
\cline { 2 - 4 } & $-0.0462^{* * *}$ & -0.0201 & $-0.0134 * * *$ \\
\hline \multirow{2}{*}{ Benchmark bond yield (5 y) } & $-0.0485^{* * *}$ & $-0.0362^{* * *}$ & $-0.0200^{* * *}$ \\
\cline { 2 - 4 } & $(0.0032)$ & $(-0.0130)$ & $(0.0023)$ \\
\hline \multirow{2}{*}{ Benchmark bond yield (2/3 y) } & $-0.0359^{* * *}$ & $-0.0324 * * *$ & $-0.0223^{* *}$ \\
\cline { 2 - 4 } & $(0.0036)$ & $(0.0055)$ & $(0.0104)$ \\
\hline \multirow{2}{*}{ CDS 10-year (USD) } & $0.0099^{* * *}$ & -0.0671 & $0.0556^{*}$ \\
\cline { 2 - 4 } & $(0.0028)$ & $(0.0633)$ & $(0.0284)$ \\
\hline \multirow{2}{*}{ CDS 5-year (USD) } & $0.0115^{* * *}$ & -0.0376 & $0.0914 *$ \\
\cline { 2 - 4 } & $(0.0033)$ & $(0.0552)$ & $(0.0480)$ \\
\hline \multirow{2}{*}{ Interbank rate (3 M) } & $-0.0339^{* *}$ & $0.0055^{* * *}$ & -0.0036 \\
\cline { 2 - 4 } & $(0.0148)$ & $(0.0013)$ & $(0.0070)$ \\
\hline \multirow{2}{*}{ Exchange Rate } & $-0.0016^{*}$ & $-0.0001 * * *$ & $0.0034 * *$ \\
\cline { 2 - 4 } & $(0.0009)$ & $(0.0000)$ & $(0.0014)$ \\
\hline \multirow{2}{*}{ Stock market index } & $0.0031^{* * *}$ & $0.0120^{* * *}$ & $0.0056^{*}$ \\
\cline { 2 - 4 } & $(0.0004)$ & $(0.0042)$ & $(0.0030)$ \\
\hline \multirow{2}{*}{ S\&P Corporate bond index } & $0.1418^{* * *}$ & 0.2627 & $0.2816^{* * *}$ \\
\cline { 2 - 4 } & $(0.0500)$ & $(0.1742)$ & $(0.1028)$ \\
\hline
\end{tabular}

Note: Newey-West standard errors in parentheses. $* * *, * *$ and $*$ display significance at the $1 \%, 5 \%$ and $10 \%$ level, respectively.

Announcements related to FWG resulted in pronounced spillover effects to financial assets from our countries of interest (see Table 7). FWG announcements affected long-term government bond yields in Norway and Sweden. Moreover, FWG announcements influenced medium-term sovereign bond yields in our 
countries of interest. As expected, medium- and long-term government bond yields were mainly affected by the signalling channel because FWG announcements were associated with decreasing government bond yields. In addition, declining government bond yields transmitted to increasing S\&P corporate bond indices in Norway and Sweden. As expected, FWG announcements led to increasing benchmark stock market indices in our countries of interest.

Furthermore, we find that FWG announcements coincided with a declining 3month interest rate in Sweden, while the FWG announcements led to an increasing 3-month interbank rate in Denmark. Hence, our results suggest that the 3-month interbank rate in Sweden was influenced by FWG announcements via the international bank lending channel. As argued before, FWG announcements were associated with an appreciation of local currencies vis-à-vis the euro in Sweden and Denmark, while FWG announcements depreciated the Norwegian krone against the euro. Finally, we find that FWG announcements affected CDS spreads in Norway and Sweden.

\section{Conclusion}

This study investigates the spillover effects of the ECB's unconventional monetary policies on small, open advanced economies. In particular, we study whether ECB announcements of non-standard monetary policies spilled over to Denmark, Norway and Sweden. We find that the ECB's announcement of unconventional monetary policies exerted substantial spillover effects on financial assets in Denmark, Norway and Sweden. In particular, the unexpected part of the ECB's non-standard policies influenced asset prices in our countries of interest.

Using a broad event set and the daily change in 10-year German Bund futures as a measure for monetary policy surprise, we show that the ECB's announcements of UMP measures resulted in substantial spillover effects of asset prices in Denmark, Norway and Sweden. The ECB's announcement of UMP measures spilled over to our countries of interest irrespective of the respective exchange rate regime. Specifically, the ECB's announcements led to declining government bond yields and increasing corporate bond indices. Hence, our results indicate that ECB announcements affected sovereign bond yields and corporate bond yields via the portfolio rebalancing channel. Hence, it seems that long- and medium-term government bonds from Denmark, Norway and Sweden are close substitutes for medium- and long-term euro area government bonds. Additionally, declining sovereign bond yields transmitted to decreasing corporate bond yields. Moreover, we find that CDS spreads in Denmark and the interbank rate in Norway were influenced by the ECB's announcement of non-standard policy measures, respectively. Our results also indicate that bilateral exchange rates and benchmark stock market indices were not affected by the ECB's announcements.

Turning to specific non-standard monetary policies of the ECB, we show that SMP announcements, CSPP announcements and forward guidance resulted in pronounced spillover effects on financial assets in Denmark, Norway and Sweden. SMP announcements in particular affected government bond yields and corporate 
bond indices. Moreover, our results indicate that asset prices in Norway were strongly influenced by SMP announcements. CSPP announcements resulted in pronounced spillover effects on government bonds, corporate bond indices and bilateral exchange rates vis-à-vis the euro. We argue that SMP announcements operated via both the portfolio rebalancing channel and the confidence channel, while CSPP influenced asset prices mainly via the confidence channel and the exchange rate channel. Statements regarding forward guidance had the most pronounced effects on asset prices in Denmark, Norway and Sweden. In particular, long- and medium-term government bond yields, stock prices and bilateral exchange rates vis-à-vis the euro were affected by FWG statements. Our results also indicate that FWG statements mainly operated via the signalling channel.

Furthermore, we find that OMT and PSPP announcements had limited spillover effects on financial assets in Denmark, Norway and Sweden. OMT announcements mainly influenced benchmark stock indices and operated via both the confidence channel and signalling channel. PSPP announcements only affected asset prices in Denmark. PSPP announcements led to declining government bond yields, decreasing corporate bond yields and increasing interbank rate in Denmark.

Our study could be extended by conducting a formal analysis of the spillover channels. With our empirical approach we could only tentatively identify the international transmission channels of the ECB's non-standard policy measures. Furthermore, the size of the spillover effects induced by the ECB's announcements of UMP measures could be compared with the effects of domestic non-standard monetary policies. An additional extension of the study could be to quantify spillover effects on macroeconomic variables in Denmark, Norway and Sweden.

\section{References}

Abbassi P, Linzert T (2012) The Effectiveness of Monetary Policy in steering Money Market Rates during the Financial Crisis. Journal of Macroeconomics 34(4): 945-954.

Altavilla C, Giannone D (2014) The Effectiveness of Non-standard Monetary Policy Measures: Evidence from Survey Data. ECARES Working Papers (2014-30).

Andrade P, Breckenfelder J, De Fiore F, Karadi P, Tristani O (2016) The ECB's Asset Purchase Programme: An Early Assessment. ECB Working Paper Series (1956).

Angelini P, Nobili A, Picillo C (2011) The Interbank Market after August 2007: What has changed, and why? Journal of Money, Credit and Banking 43(5): 923-958.

Baumeister C, Benati L (2013) Unconventional Monetary Policy and the Great Recession: Estimating the Impact of a Compression in the Yield Spread at the Zero Lower Bound. ECB Working Paper Series (1258).

Berge T, Cao G (2014) Global Effects of U.S. Monetary Policy: Is Unconventional Policy Different? Economic Review (Q I): 1-10.

Bernhard S, Ebner T (2016) Cross-border Spillover Effects of Unconventional Monetary Policies on Swiss Asset Prices. SNB Working Papers (9/2016).

Bluwstein K, Canova F (2016) Beggar-Thy-Neighbor? The International Effects of ECB Unconventional Monetary Policy Measures. International Journal of Central Banking 12 (3): 69-120.

Chen H, Cúrdia V, Ferrero A (2012) The Macroeconomic Effects of Large-scale Asset Purchase Programmes. The Economic Journal 122(564): 289-315. 
Chinn MD (2013) Global Spillovers and Domestic Monetary Policy. BIS Working Papers (436).

Diez FJ, Presno I (2014) Domestic and Foreign Announcements on Unconventional Monetary Policy and Exchange Rates. Public Policy Briefs (13-7). Federal Reserve Bank of Boston.

Falagiarda M, McQuade P, Tirpák M (2015) Spillovers from the ECB's Non-standard Monetary Policies on Non-euro area EU Countries: Evidence from an Event-study Analysis. ECB Working Paper Series (1869).

Fratzscher M, Lo Duca M, Straub R (2013) On the International Spillovers of US Quantitative Easing. ECB Working Paper Series (1557).

Fratzscher M, Lo Duca M, Straub R (2014) ECB Unconventional Monetary Policy Actions: Market Impact, International Spillovers and Transmission Channels. Paper presented at the $15^{\text {th }}$ Jacques Polak Annual Research Conference hosted by the International Monetary Fund.

Gagnon J, Raskin M, Remache J, Sack B (2011) The Financial Market Effects of the Federal Reserve's Large-scale Asset Purchases. International Journal of Central Banking 7(1): 3-43.

Gambetti L, Musso A (2017) The Macroeconomic Impact of the ECB's Expanded Asset Purchase Programme (APP). ECB Working Paper Series (2075).

Georgiadis G, Gräb J (2015) Global Financial Market Impact of the Announcement of the ECB's Extended Asset Purchase Programme, Globalization and Monetary Policy Institute Working Paper (232). Federal Reserve Bank of Dallas.

Ghysels E, Idier J, Manganelli S, Vergote O (2013) A High Frequency Assessment of the ECB Securities Markets Programme. SSRN Scholarly Paper ID 2365833, Social Science Research Network, Rochester, NY.

Glick R, Leduc S (2012) Central Bank Announcements of Asset Purchases and the Impact on Global Financial and Commodity Markets. Journal of International Money and Finance 31(8): 2078-2101.

Glick R, Leduc S (2015) Unconventional Monetary Policy and the Dollar: Conventional Signs, Unconventional Magnitudes. Working Paper Series (2015-18), Federal Reserve Bank of San Francisco.

Hume M, Sentance A (2009) The Global Credit Boom: Challenges for Macroeconomics and Policy. Journal of International Money and Finance 28(8): 1426-1461.

International Monetary Fund (IMF) (2013a) Global Impact and Challenges of Unconventional Monetary Policies. IMF Policy Paper.

International Monetary Fund (IMF) (2013b) Nordic Regional Report - Staff Report for the 2013 Cluster Consultation. IMF Country Report (13/274).

Krishnamurthy A, Vissing-Jorgensen A (2011) The Effects of Quantitative Easing on Interest Rates: Channels and Implications for Policy. NBER Working Papers (17555).

Krishnamurthy A, Nagel S, Vissing-Jorgensen A (2014) ECB Policies involving Government Bond Purchases: Impact and Channels. Unpublished Manuscript.

Lewis V, Roth M (2015) Financial Market Effects of ECB's Balance Sheet Policies. Technical report, Bundesbank.

Neely CJ (2015) Unconventional Monetary Policy had Large International Effects. Journal of Banking \& Finance 52(C): 101-111.

Peersman G (2012) Effectiveness of Unconventional Monetary Policy at the Zero Lower Bound. Meeting Paper (400), Society for Economic Dynamics.

Potjagailo G (2016) Spillover Effects from Euro Area Monetary Policy across the EU: A Factor-Augmented VAR Approach. Kiel Working Paper (2033).

Takátas E, Vela A (2014) International Monetary Policy Transmission. BIS Papers (78). 
